\title{
REGIONAL ASPECTS OF THE BIOECONOMY STRATEGY IN UKRAINE
}

OLENA KOVAL, PhD in Economics, As. Prof. Economic Theory department National University of Life and Environmental Sciences of Ukraine ORCID 0000-0001-6131-9638

E-mail: koval.o.m@nubip.edu.ua

IVAN KOVAL, student of Plant Protection, Biotechnology and Ecology faculty National University of Life and Environmental Sciences of Ukraine ORCID 0000-0001-7726-7326

E-mail: ivan.koval.515@gmail.com

\author{
OLEXANDER KOVAL, student of Mechanical and Technological faculty \\ National University of Life and Environmental Sciences of Ukraine \\ ORCID 0000-0001-8483-8094 \\ E-mail:kovka22812@gmail.com
}

\begin{abstract}
The European integration is the way of current reforms in Ukraine. The main goal of the socio-economic development is to increase the well-being of people in the country. The bioeconomy strategy leads to a sustainable bioeconomy with the higher employment in agriculture, food and drink manufacture as a result of new green jobs, healthy ecosystems, and the new bio-based products.

Biotechnology plays a key role in the following sectors of the economy: construction, agriculture, food and beverages. The importance of biotechnology is substantially reaffirmed once again during the COVID-19 virus pandemic, so that biotechnology could create the vaccine to combat the virus. Bioeconomy development is a mainstream research in the world and in Ukraine in accordance with food security, biotechnologies and environmental protection, circular economy and sustainable development.

Our comparative analysis of existing national and international strategies in particular European, with a focus on governance, builds on existing legislative documents, knowledge base network and previous work. Scientific abstraction, analyses and synthesis, logical approach and statistics on the development of the bioeconomy in the EU emphasize its socio-economic potential for the intensive development of the bioeconomy strategy in Ukraine.

The article analyze the works of scientists on the preconditions, modern features of development, indicators of macroeconomic analysis, conceptual foundations of bioeconomy strategies, mechanisms of state regulation of the agricultural economy in general and the bioeconomy in particular.

The different political approaches have many common measures to advance the economic growth with an ecological sustainability and biotechnological innovation, which increase efficiency and value-added potential. Based on the study, the authors propose to focus the attention of entrepreneurs, scientists and local governments on
\end{abstract}


the measures of regional bioeconomy strategies development for further approval of the initiative at the state level.

Keywords: agrobiocluster, biotechnology, bioeconomy, bioeconomy strategy

Introduction. To improve and innovate the way of social production, distribution, exchange and consumption of food, products and materials within healthy ecosystems is reasonable with a sustainable bioeconomy. Europe's Bioeconomy Strategy (2012) was updated in 2018 with the purpose to maximize its contribution towards the 2030 Agenda and its Sustainable Development Goals (SDGs), as well as the Paris Agreement. The bioeconomy connects economy, society and the environment with covering all sectors and systems that rely on biological resources and includes land and marine ecosystems, the services they provide, all primary production sectors that use and produce biological resources, and all economic and industrial sectors that use biological resources and processes to produce food, feed, bio-based products, energy and services. Bioeconomy has around $€ 2$ trillion in annual turnover, over 18 million people employed in EU Bioeconomy, $€ 621$ billion added value, $4.2 \%$ of the EU's GDP, $76 \%$ of employment in agriculture with food and drink manufacture. However the bioeconomy development in Ukraine is too lagging but it has great economic, social and environmental potential.

Analysis of recent researches and publications. There are a lot of scientific researches about interbranch relation, management and organization for the microand macroeconomic levels in bio-based technologies development. The connection between regional bioeconomy criteria (Talavyria M.P., Lymar V.V., Baidala V.V., 2017) are the next: environmental criteria: resource availability is clearly classified under natural resources in the supply factors and biomass availability is the first criterion identified. Economic criteria consists of: clusters; finance availability of funding to companies and new technologies; infrastructure; industrial culture and the innovation culture; the rate of formation of SMEs etc. Social criteria includes: demographic factors; collaboration between institutions and industry; regulation of the safety of bioeconomy products; public attitude and acceptance. 
The bioeconomy formation in Ukraine (Talavyria M., Koval E., Dobrivs'ka M., 2017) should be based on the innovative development of bioenergy potential of the country in the conditions of European integration. Taking full account of forming a concept for the bioeconomy development in the country and the rationale for its implementation has the objective importance. For the purpose of further intersectoral integration on the basis of biotechnologies we affirm the objective importance of agrobiocluster creating on the base of science and agrarian production combined with extension service as well.

Noteworthy is the generalized systemic approach the management mechanism of the agrarian economic systems (Vdovenko N., Baidala V., Burlaka N., Diuk A., 2018) on the basis of reorientation of management to a new qualitative level, which involves the realization of intellectual and informational resources with the maximum possible use of modeling methods and modern information technologies. The authors emphasize the need for economic integration of the agrarian sector with other branches of economy, which is reflected in the formation of the so-called agroindustrial complex with the main tasks of economic integration of the agrarian sector.

For building an effective system of sustainability management of agrarian sector development of the region and ensuring its sustainable growth in conditions of globalization scientists (Kozlovskyi S., Baidala V., Tkachuk O. and Kozyrska T., 2018) also recognized that one of the most effective instruments of state regulation of the agrarian sector development of the region could be indicative planning, methodology, technology and organization of which should be created considering the market conditions.

The Conceptual foundations of strategic development of the bioeconomy in Ukraine (Butenko V. M., 2018) argued the development of the Conception of the State strategy for the development of bioeconomy in Ukraine for the period up to 2030 in accordance with the global tendencies in the development of bioeconomy. This process should be based on the application of model of the State regulation on the principles of social partnership. We agree with the scientist's findings that in the medium term, the bioeconomy expansion allows for the number of industries entering 
the world markets with competitive reproduction of the production base will be possible with the use of biotechnology.

The leading importance of the development of bio economics and biotechnology for the agrarian sector (Rogach S., 2019) is determined based on the analysis of its potential. Bioeconomics is regarded as one of the aspects of economic activity that takes into account the positive impact of biological processes and renewable bio resources on the health of the population and the process of economic growth and development. We also believe that comparative analysis of the European ways of regulation and management of the bioeconomy development must take into account national features, the specifics of the regional biogeocenosis of territories.

Domestic scientists identify the next barriers of development the Ukrainian bioeconomy (Fedyna S.M., Kovalov B.L., Ignatchenko V.M., 2019): the biotechnology sector needs serious investment; also this area requires long and complex research and high qualification; there are barriers to reaching the world level, including complex procedures for obtaining permits and licenses; there is no necessary legislation and state system of regulation and implementation of scientific developments in this area.

Purpose of this article is to establish effective directions for the intensive development of the bioeconomy strategy in Ukraine, than to determine the features response to European priorities and policies and to demonstrate the role of Ukraine in fulfilling global Commitments as Paris Agreement, SDGs, Bioeconomy strategy.

Materials and methods of research. The methodology for this research is based on the qualitative and quantitatively analyses the legislation data, which are presented in this paper. Scientific abstraction, analyses and synthesis, logical approach and comparative analysis of the global Commitments, European policy actions and governance in Ukraine allows determining the alternative directions for the intensive development of the bioeconomy strategy in our country. Statistics on the development of the bioeconomy in the EU emphasize its socio-economic potential.

Results of the research and their discussion. The Paris Agreement (2016) detected the fundamental priority of safeguarding food security and ending hunger, 
and the particular vulnerabilities of food production systems to the adverse impacts of climate change, noting the importance of ensuring the integrity of all ecosystems, including oceans, and the protection of biodiversity. In this case the importance of education, training, public participation, access to information and cooperation at all levels exist. The threat of climate change causes food production decrease and poverty in the world. It is designed to adapt the GHG emission with the stable finance flows and to limit the temperature increase to $1.5^{\circ} \mathrm{C}$ above pre-industrial levels.

In accordance with its international obligations about the Paris Agreement, Ukraine is UN Framework Convention on Climate Change Annex I country and became the 9th country in the world which has submitted to the Secretariat of the UNFCCC Strategy of low-carbon development of Ukraine until 2050 (2018). This document provides for the reduction of emissions and increase in the absorption of greenhouse gases, the introduction of environmentally friendly production using "green" technologies in all sectors of the economy. Thus, further abandonment of fossil fuels and increased investment in renewable energy sources has been declared.

Using the UN's Sustainable Development Goals (SDGs) as an orient European key projects, sectoral policies and initiatives are based on the 2030 Agenda for Sustainable Development. Accordingly, the President of Ukraine issued a Decree On Sustainable Development Goals of Ukraine for the period till 2030 (2019), which supported ensuring the achievement of global sustainable development goals.

The EU Emissions Trading System (2005, current edition) is a major tool of the European Union in its efforts to meet emissions reductions targets. The trading approach helps to combat climate change in a cost-effective and economically efficient manner. The flexibility that trading brings means that all firms face the same carbon price and ensures that emissions are cut where it costs least to do so. Agriculture and forestry have a special status in regulation on the inclusion of greenhouse gas emissions and removals from Land use, land use change and forestry (2018). Carbon dioxide (CO2) differs from the other major greenhouse gases relevant to the sector in that the carbon can be stored in large quantities in the various carbon pools in vegetation, soils and living organisms. As an illustration, it is 
estimated that the release of just $0.1 \%$ of the carbon currently stored in European soils would equal the annual emissions from as much as 100 million cars.

Law of Ukraine on Environmental Protection (1991, current edition) determines the main principles of environmental protection: priority of environmental safety requirements; guaranteeing a safe environment for human life and health; greening of material production on the basis of use and reproduction of renewable natural resources, wide introduction of the newest technologies; preservation of spatial and species diversity and integrity of natural objects and complexes; scientifically substantiated coordination of ecological, economic and social interests of society on the basis of a combination of interdisciplinary knowledge of ecological, social, natural and technical sciences and forecasting of a condition of environment.

In Ukraine emissions of pollutants into the atmosphere by stationary sources of pollution, discharges of pollutants directly into water bodies, waste disposal, generation and temporary storage of radioactive waste are taxed by the environmental tax in accordance with the Tax Code of Ukraine (2011, current edition). The "nodebit" rule in EU predicts that GHG emissions from LULUCF are offset by at least an equivalent removal of $\mathrm{CO}_{2}$ from the atmosphere in the period 2021 to 2030.

Nowadays businesses that burn biomass from stationary sources of pollution are taxpayers for carbon dioxide emissions (according to Article 240 of the Tax Code of Ukraine). From January 1, 2019, the tax rate for carbon dioxide emissions from stationary sources has been increased from UAH 0.41. per ton up to $10 \mathrm{UAH}$. per ton. This state of affairs is not in line with world practice, as biomass is considered a $\mathrm{CO} 2$-neutral fuel, because when it is burned, carbon dioxide is formed as much as was absorbed by plants during growth. Bioenergy Association of Ukraine (2020) lobbies for the exemption of biomass combustion plants from paying $\mathrm{CO} 2$ emissions tax. It is clear that such benefits are a significant source of additional investment in the development of the country's bioeconomy.

The processes of the regional bioeconomy strategies are investigated by BioSTEP project (2018) into Stara Zagora (Bulgaria), Veneto Porto Marghera biorefinery (Italy), the Lombardy Green Chemistry cluster (Italy), Norwich Research 
Park (UK) and other. As a result of the study within some counties, regional stakeholders and policy-makers play a considerable role in the development of the bioeconomy. It shows a wide variety of cluster experiences with sectors/regions either in a still (pre)development phase as well as other regions in a phase of acceleration. The bioeconomy sectors biofuels, "green" chemicals, and food and feed additives are reported most frequently. In most cases, regions within a (pre)development phase are agriculture-based and hence show the importance of food and feedstock connected to the bioeconomy sector.

Previously, in order to provide the city with food there were no problems, everything that was needed was produced by farms in its area. Now with the development of transport links and the growth of cities, in stores we can see that a very small percentage of goods were manufactured or grown in the region. We believe that the regions should not just be provided with the imported goods of civilization, but should be helped in part so that they can develop their own markets for goods and services and infrastructure. Consolidation and grouping of producers on the basis of biotechnology provides benefits from cooperation, which increases the export potential of regions in the context of globalization.

In accordance with the European Cluster Observatories (2015) methodology opportunities for clusters in the city of Kyiv and Kyiv region are based on research and experimental development in biotechnology. According to the State Statistics Service of Ukraine, the volume of sold products (goods and services) in agriculture, forestry and fisheries in 2018 amounted to $10.4 \%$ by large enterprises, $51.9 \%$ by medium-sized enterprises, $37.7 \%$ by small enterprises, of which $11,6 \%$ are microenterprises. At the same time, $100 \%$ of large enterprises, $88.5 \%$ of medium-sized enterprises and $86.2 \%$ of small enterprises get a profit. So, for preference it is necessary to enlarge and to consoled SMEs to intensify the bioeconomy of the region. It should be implemented in the Development Strategy of Kyiv region for 2021-2027 (2020), which is based on the available resource potential.

Conclusions and future perspectives. Maximum acceleration of the implementation of the Association Agreement with the European Union provides 
opportunities for political association and economic integration for Ukraine. The issue of environmental protection is quite acute, because it is an agrarian country and the main income from export is from the sale of cereals $19 \%$, animal or plant fats and oils $-12 \%$, finished food industry products $-6.8 \%$ and wood and articles of wood $-2.9 \%$ of the total volume. Therefore, it is necessary to take care of the condition and quality of land and other natural resources. Bio-based sectors develop the sustainable, renewable, innovative and efficient economic system.

A significant contribution to the preservation of the environment is the education of citizens with an information infrastructure development. The collaboration of the scientist with a broad group of entrepreneurs and publics through advisory services which support the bio-based markets and the entrepreneur activity of SMEs, communication, consultation, and practices exchange, helps connecting the developing bioeconomy more strongly to society.

The bioeconomy clusters that are still in a phase of predevelopment have prospects for development on biotechnologies, which in the future is a prerequisite for the formation of regional bioeconomy strategies general in Ukraine and Kyiv region in particular. Science, business and government must work together to improve the living standards of the population in the face of increasing international competition and globalization. Forms and methods of collaboration are issues that deserve further discussion.

\section{References:}

1. The Bioeconomy Strategy of European Union (2012). Retrieved from: https://ec.europa.eu/research/bioeconomy/index.cfm?pg=policy\&lib=strategy

2. Talavyria M. P., Lymar V. V., Baidala V. V. (2017) Indicators for analysis of the bioeconomy in Ukraine. Ekonomika APK, 3: 44-50. Retrieved from: http://eapk.org.ua/sites/default/files/eapk/2017/3/e_apk_2017_3_8.pdf

3. Talavyria M.P., Koval O.M., Dobrivska M.V. (2017) Rrozvytok bioenerhetychnoho potentsialu $\mathrm{v}$ Ukraini [Bioenergy potential development in Ukraine]. Visnyk Kharkivskoho natsionalnoho ahrarnoho universytetu im. V.V. Dokuchaieva. Seriia ekonomichni nauky, 12: 229-238 (in Ukrainian)

4. Nataliia Vdovenko, Viktoriia Baidala, Nelya Burlaka and Anna Diuk (2018). Management mechanism of agrarian economic system: composition, functions and 
factors of development in Ukraine. Problems and Perspectives in Management, 16(2): 179-189. doi:10.21511/ppm.16(2).2018.16

5. Serhii Kozlovskyi, Viktoriia Baidala, Olga Tkachuk and Tetiana Kozyrska (2018) Managament of the Sustainable Development of the Agrarian Sector of the Regions of Ukraine. Montenegrin Journal of Economics, 14(4):175-190. DOI: 10.14254/1800-5845/2018.14-4.12

6. Butenko V. M. (2018) Kontseptualni zasady stratehichnoho rozvytku bioekonomiky v Ukraini. [The Conceptual Foundations of Strategic Development of the Bioeconomy in Ukraine]. Biznesinfor, 6: 69 - 75 (in Ukrainian)

7. Rohach S.M. (2019) Yevropeiskyi dosvid rozvytku ahrarnoho sektoru na bioekonomichnykh zasadakh. [European experience of agricultural sector development on bio economic principles]. Pryazovskyi ekonomichnyi visnyk, 4(15): 208 - 215. DOI: https://doi.org/10.32840/2522-4263/2019-4-35 (in Ukrainian)

8. Fedyna S. M., Kovalov B. L., Ihnatchenko V. M. (2019) Bioekonomika: sutnist poniattia, stratehii, stan ta perspektyvy rozvytku form $\mathrm{v}$ Ukraini. [Bioeconomics: the Essence of the Concept, Strategies, Status and Prospects of Development of Entrepreneurial Forms in Ukraine]. Mekhanizm rehuliuvannia ekonomiky, 3: 16 - 27. https://doi.org/10.21272/mer.2019.85.02 (in Ukrainian)

9. The Paris Agreement (2015). Retrieved from: https://unfccc.int/process-andmeetings/the-paris-agreement/the-paris-agreement

10. Strategy of low-carbon development of Ukraine until 2050 (2018). Ministry of Ecology and Natural Resources of Ukraine. Retrieved from: https://mepr.gov.ua/news/32615.html

11. 2030 Agenda for Sustainable Development (2015). Retrieved from: https://www.un.org/sustainabledevelopment/development-agenda/

12. On Sustainable Development Goals of Ukraine for the period till 2030 (2019). Decree. Retrieved from: https://zakon.rada.gov.ua/laws/show/722/2019\#Text

13. The EU Emissions Trading System (2005, current edition). Retrieved from: https://ec.europa.eu/clima/policies/ets_en

14. Land use, land use change and forestry (2018). Land-based emmicion. EU Climate Action. Retrieved from: https://ec.europa.eu/clima/policies/forests

15. Law of Ukraine on Environmental Protection (1991, current edition). Retrieved from: https://zakon.rada.gov.ua/laws/show/1264-12\#Text

16. Tax Code of Ukraine (2011, current edition). Retrieved from: https://zakon.rada.gov.ua/laws/show/en/2755-17?find=1\&lang=en\&text=240\#Text

17. Bioenergy Association of Ukraine (2020). Retrieved from: https://uabio.org/news/499/

18. BioSTEP project (2018) website. Retrieved from: http://www.biostep.eu/background/bioeconomy-strategies.html

19. European Cluster Observatory (2015). Retrieved from: http://www.clusterobservatory.eu/index.html

20. Development Strategy of Kyiv region for 2021-2027 (2020). Kyiv regional state administration. Retrieved from: http://koda.gov.ua/ 


\section{РЕГІОНАЛЬНІ АСПЕКТИ СТРАТЕГІЇ РОЗВИТКУ БІОЕКОНОМІКИ УКРАЇНИ

\author{
О. М. Коваль, І. О. Коваль, О. О. Коваль,
}

Анотація. Свропейська інтеграчія - шлях нинішніх реформ в Украӥні. Головною метою сочіально-економічного розвитку є підвищення добробуту людей у краӥні. Стратегія біоекономіки веде до стійкої біоекономіки з вищим рівнем зайнятості в сільському господарстві, виробництві продуктів харчування та напоїв у результаті нових «зелених» робочих місиь, здорових екосистем та нових продуктів на біологічній основі.

Біотехнологія відіграє ключову роль у таких галузях економіки: будівництві, сільському господарстві, виробництві продуктів харчування та напоїв. Важливість біотехнології ще раз підтверджується під час пандемії вірусу COVID-19, тому щзо біотехнологія має можливість створити вакиину для боротьби з вірусом. Розвиток біоекономіки є основним дослідженням у світі та Украӥні відповідно до продовольчої безпеки, біотехнологій та охорони довкілля, економіки замкнутого ииклу та сталого розвитку.

Наш порівняльний аналіз сучасних начіональних та міжнародних стратегій, зокрема європейських, з акцентом на управління, трунтується на сучасних законодавчих документах, мережі баз знань та попередній роботі. Наукова абстракиія, аналіз та синтез, логічний підхід та статистика розвитку біоекономіки в ЄС підкреслюють його соціально-економічний потенціал для інтенсивного розвитку стратегії біоекономіки в Україні.

У статті аналізуються роботи вчених про передумови, сучасні особливості розвитку, показники макроекономічного аналізу, конщептуальні основи стратегій біоекономіки, механізми державного регулювання аграрної економіки загалом та біоекономіки зокрема.

Різні політичні підходи мають багато спільних заходів для сприяння економічному зростанню за допомогою екологічної стійкості та біотехнологічних інновацій, які підвищують ефективність та потенціал доданої вартості. На основі дослідження автори пропонують зосередити увагу підприємиів, науковиів та органів місиевого самоврядування на заходах із розвитку регіональних стратегій біоекономіки для подальшого затвердження ініціативи на державному рівні.

Ключові слова: агробіокластер, біотехнологія, біоекономіка, стратегія біоекономіки. 